\title{
Türkiye'deki İşletmelerin Rekabet Kazanımlarında Kullandıkları Stratejik Yönetim Anlayışlarının Etkileri: Sistematik Bir İnceleme
}

\author{
Canan TíFTík
}

\section{$\ddot{O} z$}

21. yüzyılda her tür ve düzeydeki örgüt, varlğı̆ı sürdürmek ve gelişebilmek için rekabet etmeyi, ürün kalitesini artırmayı veya verdiği hizmetlerde verimliliği sağlamayı hedeflemelidir. Değișim ve dönüșümün oldukça sık yaşandığı, rekabet edebilme becerilerinin hayati önem taşıdığı günümüz dünyasında örgütler, varlıklarını sürdürebilmek ve etkili olabilmek için sahip oldukları kaynakları etkili ve verimli kullanmak zorundadır. Araştırmanın odak noktası olan stratejik yönetim anlayışı işletmeler için en önemli konulardan birisi olup işletmelerin hedeflerini gerçekleștirmek için mevcut kaynaklarını en uygun ve en faydalı șekilde kullanmayı arzu ederler. Bunun en uygun yollarından biri avantajl yönlerini kullanarak dezavantajları bertaraf etmek ve firsatlardan faydalanarak tehditleri minimum seviyeye indirmektir. Bu araştırmanın amacl, Türkiye'deki işletmelerin rekabet kazanımlarında kullandıkları stratejik yönetim anlayışlarının etkilerinin güncel ulusal alanyazında yapılmış araştırmalar üzerinden sistematik olarak incelenmesidir. Araştırmanın yöntemi, betimsel tipte nitel sistematik derlemedir. Araştırmanın çalışma dokümanını Ocak 2020-Ekim 2021 yılları arasında ulusal alanyazında işletmelerin rekabet kazanımlarında kullandıkları stratejik yönetim anlayışlarının etkileri üzerine yapılmış 11 araştırmadan oluşturmaktadır. Araştırmanın çalışma dokümanını oluşturan araştırmalar uzman görüşleri ışı̆̆ında araştırmacı tarafindan belirlenen 6 analiz parametresine göre (amaç, araştırma modeli, araștırmanın örneklemi, veri toplama araçları, verilerin analizi ve sonuçlar) incelenmiștir. Araștırma sonuçları; belirlenen analiz parametrelerine göre güncel ulusal alanyazında Türkiye'deki ișletmelerin rekabet kazanımlarında kullandıkları stratejik yönetim anlayıșlarının etkilerine yönelik sonuçlarının çıktılarının değerlendirilmesi yapılmıştır. Araştırma sonuçlarına göre; işletmelerin rekabet sağlamalarında dijital mecralarda uygulanan stratejiler, dijital ortamlardan gelen yeni ve çok büyük miktarda verinin nasıl yönetileceği ve daha da daralan müsteri segmentlerine yönelik teklifleri ve mesajları daha iyi kişiselleştirmek için verilerin nasıl kullanılacağının düşünülmesi gerektiği söylenebilir. Yapılan bu sistematik inceleme araştırmasının stratejik yönetim ve rekabet konu kapsamı çerçevesine yönelik yapılacak yeni çalışmalara ve konuyla ilgili işletmelere kaktı sağlayacağı düşünülmektedir.

Anahtar Kelimeler: Sistematik İnceleme, İşletme Yönetimi, Rekabet, Strateji, Stratejik Yönetim.

Jel Kodlart: M10, M19, L21, L10

The Effects of Strategic Management Approaches Used By Businesses in Turkey on Their Competitive Gain: A Systematic Analysis

\begin{abstract}
Organizations of all types and levels in the $21^{\text {st }}$ century should try to compete, raise product quality or assure efficiency in the services they provide in order to survive and thrive. In today's environment, when change and transformation are experienced regularly and competitiveness skills are crucial, businesses have to manage their resources effectively and efficiently in order to survive and be effective. Strategic management, which is the topic of the research, is one of the most critical concerns for businesses, and organizations aim to use their

Derleme Makale (Review Article)

Geliş/Received: 15.12 .2021

Kabul/Accepted: 28.01 .2022

${ }^{*}$ Dr. Öğr. Üyesi, İstanbul Gelişim Üniversitesi, Uygulamalı Bilimler Fakültesi, İstanbul, Türkiye,

E-posta: ctiftik@gelisim.edu.tr ORCID https://orcid.org/0000-0002-8327-5282
\end{abstract}


Canan Tiftik, “Türkiye'deki İşletmelerin Rekabet Kazanımlarında Kullandıkları Stratejik Yönetim Anlayışlarının Etkileri: Sistematik Bir İnceleme”, İzlek Akademik Dergi (Izlek Academical Journal), 4 (1), 2021, ss. 45-55.

existing resources in the most appropriate and most beneficial way to achieve their goals. One of the most acceptable ways to do this is to eliminate the disadvantages by leveraging its positive characteristics and to limit the threats by taking advantage of the possibilities. The purpose of this research is to systematically investigate the consequences of strategic management approaches employed by enterprises in Turkey in their competitive gains, through the researches performed in the present national literature. The method of the research is a descriptive qualitative systematic review. The working document of the research consists of 11 studies done between January 2020 and October 2021 on the consequences of strategic management approaches used by firms in competitive gains in the national literature. The studies that compose the working document of the research were analyzed according to the 6 analysis parameters (purpose, research model, sample of the research, data collection instruments, data analysis and findings) defined by the researcher in the light of expert opinions. Research outcomes; According to the analysis parameters set, the outcomes of the results of the strategic management approaches utilized by the enterprises in Turkey in the present national literature on the competitive gains were analyzed. According to the results of the research; It can be said that the strategies applied in digital media for businesses to compete, how to manage new and huge amounts of data coming from digital media and how to use data to better personalize offers and messages for ever narrowing customer segments should be considered. It is expected that this systematic review research will contribute to the future studies to be done on the scope of strategic management and competition and to the companies associated to the subject.

Keywords: Systematic Review, Business Management, Strategy, Competition, Strategic Management.

Jel Codes: M10, M19, L21, L10

\section{Giriş}

İşletme yönetimi bir işletmenin hem iç çevresinde hem de dış çevresinde gelişen olayları, bu olayların nedenlerini ve sonuçlarını inceleyen bir bilim olduğundan işletmeler değişen çevresel şartları analiz edip, işletme biliminin ilke ve uygulamalarını uygulayarak işletmelerini bu şartlara adapte etmek gayesindedirler. Buna göre işletmelerin temel amacı ellerindeki kısıtlı kaynaklar ile işletmelerini amaç ve hedeflerine ulaştırmaktır. Ancak hızla değişen çevresel koşullar amaca giden yola sürekli engeller koymakta ve işletmeciliğin temel amacı olan etkili ve verimli mal veya hizmet üretimini zorlaştırmaktadır.

Araştırmanın odak noktası olan stratejik yönetim anlayışı işletmeler için en önemli konulardan birisidir. Çünkü bu yöntem anlayışı işletmelerin hedeflerini gerçekleştirmek için mevcut kaynaklarını en uygun ve en faydalı şekilde kullanmayı arzu ederler. Bunun en uygun yollarından biri stratejik yöntemlerin avantajlı yönlerini kullanarak dezavantajları bertaraf etmek ve firsatlardan faydalanarak tehditleri minimum seviyeye indirmektir. İşletmelerin bu planlarından meydana gelen strateji, aslında geleceğe dönük bir çalışma bir projeksiyondur. Bu çalışmaları başarıyla gerçekleștiren işletmelerin rakiplerinden daima önde oldukları gözlemlenmiştir (Adabor, 2019). Günümüzde yaşanan Covid-19 pandemisini de etkili ve verimli mal/hizmet üretimi amacı önünde duran önemli bir engel olarak tanımlamak mümkündür. Araştırma kapsamında güncel ulusal alanyazından işletmelerin rekabet kazanımlarında kullandıkları stratejik yönetim anlayışlarının etkilerinden elde edilen çıktıların işletme yönetiminde yapılacak gelecek tahminlerinin kıymetini ortaya koyacağı düşünülmektedir. Çünkü yeni normal olarak adlandırılan bu süreçte işletmelerin geleceği ile ilgili tahminler yürüterek stratejik yönetim anlayışları geliştirmesi kolay değildir. Zaten son yıllarda özellikle küreselleşme, pazarlamanın üzerine inşa edildiği ana konularda değişimi zorlamıştır. Küreselleşme ile birlikte insanların ürünlere hızlı ve kolay ulaşımı, rekabeti artırmış, ürünlerin birbirlerine kıyasla avantajlarını 
Canan Tiftik, “Türkiye'deki İşletmelerin Rekabet Kazanımlarında Kullandıkları Stratejik Yönetim Anlayışlarının Etkileri: Sistematik Bir İnceleme”, İzlek Akademik Dergi (Izlek Academical Journal), 4 (1), 2021, ss. 45-55.

minimuma indirmiş, zevk ve tercihler değişmiştir. $\mathrm{Bu}$ durumdan bazı işletmeler olumsuz etkilenirken bazılarına da firsat yaratmış ve başarılı olmuşlardır. Küreselleşmenin etkisiyle kurulan yeni iş alanları, yeni istihdam şekilleri de gözlemlenmiştir.

Şüphesiz Covid-19 salgını ile birlikte tüm dünya birçok konuda ve belli ölçülerde mahrumiyet yaşamaktadır. Bu mahrumiyetin kapsamını, işletmeler açısından ele aldığımızda her sektörün aynı derecede ve aynı şiddette negatif yönlü etkilendiğini söylemek mümkün değildir. Sektörlerin farklı etkilenme düzeyleri ve farklı toparlanma beklentileri bir arada düşünüldügünde akla iki soru gelmektedir: Bunlardan birinci soru, salgın sonrası akademi dünyasında işletme yönetimi bilimi ne yapacaktır, seyrinde bir değişiklik olacak mıdır? İkinci soru ise iş dünyasının rekabet kazanımlarında taktik ve stratejilerinin seyri ne olacaktır?

Genellikle bir konunun geleceği ile ilgili öngörülerde bulunurken bütüncül bir yaklaşım sergilenir. Oysa konu işletme yönetimi gibi çok yönlü bir yapı ise geleceğe dönük söylemlerde konunun ana boyutlarının ayrı ayrı irdelenmesi gerekmektedir. Çünkü bu alan uygulamalı bir bilim dalı olup alanın var olma ve çalışma prensibi bu şekilde işlemektedir. Bu nedenle yapılan nicel ve nitel araștırmalar gibi sistematik inceleme araștırmaları da bir ihtiyaçtır. Uygulamaya geçmemiș veya yaygınlık kazanmamış kuramsal fikirler pazarlama bilimi içinde gelecekte anlamlı hale gelebilir. $\mathrm{Bu}$ bağlamdan yola çıkılarak araştırmanın amacl, Türkiye'deki işletmelerin rekabet kazanımlarında kullandıkları stratejik yönetim anlayışlarının etkilerinin güncel ulusal alanyazında yapılmıș araştırmalar üzerinden sistematik olarak incelenmesidir. Araştırmanın sonuçlarının pandemi sürecinde yapılan araștırmaların sistematik incelemesiyle ilgili alanyazına ve işletmelerin yeni normalde uyguladıkları rekabet avantajları ve stratejik yönetim anlayışlarındaki değişikliklere katkı sağlayacağı düşünülmektedir.

\section{YÖNTEM}

\subsection{Araştırmanın Modeli}

Araştırmanın yöntemi betimsel tipte nitel sistematik derlemedir. Betimsel tipte nitel sistematik derleme yöntemi, araştırmacının herhangi bir konu veya disipline ilişkin genel eğilim ve araştırma sonuçlarını ortaya koymak adına gerçekleştirdiği bir sistematik derleme yöntemi olarak tanımlanmaktadır (Calik ve Sözbilir, 2014). Bu yöntemde araştırmacının amacı çoğunlukla seçtiği konuyla ilişkili olarak yapılan akademik çalışmaların amaçlarını, hangi kuramsal çerçeveye ve yönteme dayandığını ve araştırmaların bulgularını ortaya koymaktır (Hallinger, 2018).

\section{2. Çalışma Dokümanı ve Verilerin Toplanması}

Araştırma için verilerin toplanması aşamasında 10 Ekim 2021 tarihinde Google Akademik veri tabanı kullanılarak tarama gerçekleştirilmiştir. Google Akademik'in diğer veritabanlarına kıyasla sosyal bilim disiplinleri için marjinal bir öneme sahip olduğu düşünülmektedir (Cebeci, 2021). Araştırmaya dâhil edilen araştırmaların tarama ölçütleri: başlık ve özet alanında "stratejik yönetim; rekabet" kelime/kelime gruplarının gelişmiş arama seçeneği kullanılması ve doküman türünün makale (article) olması ile sınırlandırılmıştır. Tarama Ocak 2020- Ekim 2021 tarihleri arasında sınırlandırılmıştır. Buna göre araştırmaya dâhil edilme ölçütleri; araştırmanın tam metnine ulaşılabilir olmasıdır. Araştırmaya dâhil edilmeme/dışlanma ölçütleri ise; araştırma yöntemi olarak deneysel olmayan araştırmalar, derlemeler, olgu sunumları, meta analizler ve editoryal materyal yazıları, kısa anket araştırmaları ve yinelenen makaleler dışlanmıștır. 
Canan Tiftik, “Türkiye'deki İşletmelerin Rekabet Kazanımlarında Kullandıkları Stratejik Yönetim Anlayışlarının Etkileri: Sistematik Bir İnceleme”, İzlek Akademik Dergi (Izlek Academical Journal), 4 (1), 2021, ss. 45-55.

\subsection{Verilerin Toplama Araçları}

Araştırmanın veri toplama aracı olarak Çağlı (2019) ve Orakcıoğlu (2019)'un araştırmalarında kullandıkları parametreler ele alınarak araştırmacı tarafından birleştirerek kullanmıştır. Bu başlıklar aşağıda verilmiştir:

- Araştırmanın amacl,

- Araştırma modeli,

- Veri toplama araçları,

- Verilerin analizi ve

- Sonuçlar.

\section{BULGULAR}

Araştırmanın amacı kapsamında Türkiye'deki işletmelerin rekabet kazanımlarında kullandıkları stratejik yönetim anlayışlarının etkileri sistematik olarak incelenmiştir. Buna göre çalışma dokümanında yer alan araştırmalar araştırmacı tarafından belirlenen 6 parametreye (amaç, araştırma modeli, araştırmanın örneklemi, veri toplama araçları, sonuçlar) göre elde edilen bulgular aşağıda her bir araştırma için ayrı ayrı verilmiştir:

Erdağ ve Yaşlıoğlu (2020) tarafından yapılmış araştırmanın;

- Amacı; farklı rekabet stratejileri benimseyen havayollarının kabin görevlilerinin algıladıkları örgütsel desteğin, örgütsel sessizlik üzerinde farklı etkilerinin incelenmesidir.

- Araştırmanın modeli; yapısal eşitlik modellemesidir.

- Araştırmanın örneklemi; basit tesadüfi örnekleme yöntemi ile belirlenen 240 kabin görevlisinden oluşmaktadır.

- Veri toplama araçları; Örgütsel Destek ve Örgütsel Sessizlik ölçekleridir.

- Araştırma verilerinin analizinde; betimsel tanımlayıcı analiz ve korelasyon analizleri kullanılmıştır.

- Araştırmanın sonuçları; havayolu işletmelerinin rekabet stratejisine göre uyguladıkları iş modelinin örgüt yapısı ve ilgili uygulamaların kabin görevlilerinin algıladıkları örgütsel destek ve örgütsel sessizlik düzeyleri üzerinde etkili olduğu belirlenmiştir.

Özdemir ve Taşcı (2020) tarafından yapılmış araştırmanın;

- Amacı, kaynak temelli görüş ekseninde firmaların sahip olduğu örgütsel kaynakların rekabet stratejileri üzerindeki etkisinin incelenmesidir.

- Araştırmanın modeli; nicel araştırma yöntemlerinden ilişkisel tarama modelidir.

- Araştırmanın evreni; İstanbul Sanayi Odası (ISO) tarafından belirlenen Türkiye'nin ilk 1000 büyük sanayi firmalarından oluşmaktadır. Araştırmanın örneklemi ise; farklı düzeydeki 211 teknoloji firmasından oluşmaktadır.

- Araştırmanın veri toplama araçları; entelektüel sermaye ve rekabet stratejileri ölçeğidir.

- Araştırma verilerinin analizinde; pearson moment korelasyon katsayl değerleri, regresyon analizi, ikiden fazla bağımsız grup için tek yönlü varyans analizi, varyans analizinde gruplar arasındaki farklılığın hangi grup ya da gruplardan kaynaklandığının belirlenmesi için Tukey testi kullanılarak gerçekleştirilmiştir. 
Canan Tiftik, “Türkiye'deki İşletmelerin Rekabet Kazanımlarında Kullandıkları Stratejik Yönetim Anlayışlarının Etkileri: Sistematik Bir İnceleme”, İzlek Akademik Dergi (Izlek Academical Journal), 4 (1), 2021, ss. 45-55.

- Araştırmanın sonuçları; farklı düzeyde faaliyet gösterilen firmaların düzeylerine göre farklılaşma stratejisi ve sosyal sermayenin anlamlı şekilde etkilediği saptanmıştır.

Kaya, Batman ve Türkay (2021) tarafından yapılmış araştırmanın;

- Amacı: Trabzon'da faaliyet gösteren otel işletmelerinin başarı ve rekabet avantajı kapsamında odaklanması gereken etkenlerin ele alınmasıdır.

- Araştırmanın modeli; nicel ve nitel araştırma yöntemleri bir arada kullanıldığından karma araştırma yöntemidir.

- Araştırmanın nicel örneklemi 19 otel yöneticisinden; nitel çalışma grubu ise 10 otel yöneticisinden oluşmaktadır.

- Araştırmanın veri toplama araçları; nicel veri toplama aracı Kritik Başarı Faktörleri ölçeği, nitel veri toplama aracı yarı yapılandırılmış görüşme formudur.

- Araştırmanın nicel verilerin analizinde; ortalama ve standart sapma; nitel verilerin analizinde ise tek ve iki vaka modeli ile kelime bulutu kullanılmıștır.

- Araştırma sonuçlarına göre; otel işletmelerinin başarı ve rekabet avantajı kapsamında odaklanması gereken etkenlerden en önemlilerinin ek hizmetler, misafir ile iletişim, otel odalarının dizaynı ve kalitesi, misafir tavsiyeleri, uluslararası marka oluşturma ve işletmenin sosyal medyadaki etkinliğidir.

Çelik (2020) tarafından yapılmış araştırmanın;

- Amacı; endüstri 4.0 uygulamaları ile firmaların büyüklüğüne göre seçtikleri rekabet stratejileri arasındaki ilişkinin incelenmesidir.

- Araștırmanın modeli; nicel araştırma yöntemlerinden ilişkisel tarama modelidir.

- Araştırmanın örneklemi ulaşılabilir örnekleme yöntemi ile 102 firmadan oluşmuştur.

- Araştırmanın veri toplama araçları; maliyet lideliği stratejisi, farklılaştırma stratejisi ve Endüstri 4.0 ölçeği'dir.

- Araştırmanın verilerin analizinde; ANOVA analizi kullanılmıștır.

- Araştırma sonuçlarına göre; endüstri 4.0 ile firma büyüklüğü arasında istatistiksel olarak anlamlı ilișki saptanmazken rekabet stratejilerinden olan farklılaştırma stratejisi ile firma büyüklüğü arasında istatistiksel olarak anlamlı ilişki saptanmıştır.

Yıldız ve Genç (2020) tarafından yapılmış araştırmanın;

- Amacı; Ordu ilinde faaliyet gösteren işletmelerin örgütsel yapı ve performans ölçütü açısından rekabet üstünlüğüne ulaşma düzeylerinin arasındaki ilişkilerin farklı demografik değişkenlere göre incelenmesidir.

- Araştırmanın modeli; nicel araştırma yöntemlerinden ilişkisel tarama modelidir.

- Araştırmanın evrenini Ordu ilinde farklı sektörlerde faaliyet gösteren işletmelerden oluşurken araştırmanın örneklemi ise 33 işletmeden oluşmuştur.

- Araştırmanın veri toplama aracı olarak; İnsan Sermayesi ve Algılanan Örgütsel Performans Ölçeği kullanılmıştır.

- Araştırmanın verilerin analizinde; korelasyon analizi kullanılmıştır. 
Canan Tiftik, “Türkiye'deki İşletmelerin Rekabet Kazanımlarında Kullandıkları Stratejik Yönetim Anlayışlarının Etkileri: Sistematik Bir İnceleme”, İzlek Akademik Dergi (Izlek Academical Journal), 4 (1), 2021, ss. 45-55.

- Araştırmanın sonucuna göre; insan sermayesi ile örgütsel performans arasında, istatistiksel olarak anlamlı ilişki saptanmazken, örgüte özgü insan sermayesi ile örgütsel performans arasında istatistiksel olarak anlamlı ve pozitif ilişki saptanmıştır.

Yıldırım (2020) tarafından yapılmış araştırmanın;

- Amacı; dönüştürücü liderliğin rekabet zekâsına etkisinde örgütsel öğrenmenin aracıllk rolünün incelenmesidir.

- Araştırmanın modeli; nicel araştırma yöntemlerinden ilişkisel tarama modelidir.

- Araştırmanın örneklemi; otellerde faaliyet gösteren 208 alt, orta ve üst düzey yöneticiden oluşmaktadır.

- Araştırmanın veri toplama araçları; Dönüştürücü Liderlik, Örgütsel Öğrenme ve Rekabet Zekâsı Ölçeğidir.

- Araştırmanın veri analizleri; yapısal eşitlik modellemesi ile yapılmıştır.

- Araştırmanın sonuçlarına göre; dönüştürücü liderlikle örgütsel öğrenme ve rekabet zekâsı arasında olumlu yönde istatistiksel olarak anlamlı etkisi olduğu saptanmıştır. Ayrıca örgütsel öğrenme ile rekabet zekâsı arasında da istatistiksel olarak olumlu yönde anlamlı etkisi olduğundan aracı rolü olduğu belirlenmiștir.

Özer, Saldamlı ve Cinnioğlu (2021) tarafından yapılmış araştırmanın;

- Amacı; stratejik yetenek yönetimi ile sürdürülebilir rekabet avantajı arasındaki ilişkiyi ortaya çıkarmak ve örgütsel bağlılığın bu ilişkide bir rol oynayıp oynamadığının incelenmesidir.

- Araştırmanın modeli; nicel araştırma yöntemlerinden ilişsisel tarama modelidir.

- Araştırmanın örneklemi; 126 otel işletmesinde çalışan toplam 391 yöneticiden oluşmaktadır.

- Araştırmanın veri toplama aracı; Stratejik Yetenek Yönetimi Ölçeği, Sürdürülebilir Rekabet Avantajı Ölçeği ve örgütsel bağlılık Ölçeğidir.

- Araştırmanın verilerin analizinde; tanımlayıcı istatistik ve korelasyon analizi kullanılmıştır.

- Araştırmanın sonuçlarına göre; stratejik yetenek yönetiminin sürdürülebilir rekabet avantajı ve örgütsel bağlılık üzerinde önemli etkisi olduğu, stratejik yetenek yönetiminin örgütsel bağlılık üzerinde önemli etkisi olduğu belirlenmiștir.

Dursun (2021) tarafından yapılmış araştırmanın;

- Amacl; örgütsel performans ile jenerik rekabet stratejilerinin etkisinin incelenmesidir.

- Araştırmanın modeli; nicel araştırma yöntemlerinden ilişkisel tarama modelidir.

- Araştırmanın örneklemi; tarım endüstrisinde faaliyet gösteren kamusal bir işletmede çalışan 42 katılımcıdan oluşmaktadır.

- Araştırmanın veri toplama araçları; Stratejik İnsan Kaynakları Yönetimi, Jenerik Rekabet stratejileri ve Örgütsel Performans Ölçeği'dir.

- Araştırmada elde edilen verilerin analizinde regresyon analizi kullanılmıştır. 
Canan Tiftik, “Türkiye'deki İşletmelerin Rekabet Kazanımlarında Kullandıkları Stratejik Yönetim Anlayışlarının Etkileri: Sistematik Bir İnceleme”, İzlek Akademik Dergi (Izlek Academical Journal), 4 (1), 2021, ss. 45-55.

- Araştırmanın sonuçlarına göre; rekabet stratejilerinin farklılaştırma stratejisi boyutunun örgütsel performans ile insan kaynakları yöntemi stratejileri üzerinde etkisi olduğu belirlenmiştir.

Yıldırım ve Çakırlı (2021) tarafından yapılmış araştırmanın;

- Amacı; konaklama işletmelerinin rekabet etmede avantaj sağladığı kaynakları belirlemek olup araştırma için örnek olarak Bodrum/Muğla destinasyonu seçilmiştir.

- Araştırmanın modeli; nitel araştırma yöntemlerinden durum çalışmasıdır.

- Araştırmanın çalışma grubu; Bodrum'da faaliyet gösteren 36 adet 5 yıldızlı konaklama işletmelerinden gönüllülük esasına dayalı olarak mülakat yapmayı kabul eden 16 konaklama işletmesidir.

- Araştırmanın veri toplama aracı; yarı yapılandırılmış görüşme tekniği olup 10 açık uçlu sorudan oluşmaktadır.

- Araştırmanın verilerinin analizinde içerik analizi tekniği kullanılmıştır.

- Araştırmanın sonuçlarına göre; konaklama işletmeleri arasında yoğun bir rekabetin yaşandığı ve işletmelerin kaliteli hizmet için çalışan personele, fiyat-kalite dengesini sağlamaya, tedarikçileri ile iyi ikili ilişkiler kurmaya, müşteri geri bildirimlerini dikkatli şekilde takip etmeye özen gösterdikleri belirlenmiştir.

Çatı ve Çılkmak (2021) tarafından yapılmış araştırmanın;

- Amacı; üretim işletmelerinin, lojistik faaliyetleri açısından rekabet avantajı sağlaması konusundaki algılarının incelenmesidir.

- Araştırmanın modeli; nicel araştırma yöntemlerinden ilişkisel tarama modelidir.

- Araştırmanın örneklemini Düzce ilinde üretim alanında faaliyet gösteren 253 işletmeden oluşmaktadır.

- Araştırmanın veri toplama aracı olarak Rekabet Avantajı Ölçeği kullanılmıştır.

- Araştırmanın verilerin analizinde; tanımlayıcı istatistiksel analiz, ANOVA, t-testi, KruskalWallis ve korelasyon analizi kullanılmıştır.

- Araştırmanın sonucuna göre; işletmelerin rekabet güçlerini ölçme kriterleri ile lojistik faaliyetlerin üstünlüğü arasında da anlamlı bir ilişkinin olduğu belirlenmiştir.

Burak ve Deniz (2021) tarafından yapılan araştırmanın;

- Amacı; kurum kültürü, sürdürülebilir rekabet avantajı, çevresel belirsizlik ve kurumsal performans ilişkisinin Türk ihracatçı firmalarında incelenmesidir.

- Araştırmanın modeli; nicel araştırma yöntemlerinden ilişkisel tarama modelidir.

- Araştırmanın örneklemi; Türkiye İhracatçılar Meclisi'nin 2018 yılında yayınladığı ilk 1000 ihracatçı işletme listesinde yer alan 260 işletmenin yöneticilerinden oluşmaktadır.

- Araştırmanın veri toplama aracı; Kurum Kültürü, Sürdürülebilir Rekabet Avantajı ve Kurumsal Performans Ölçeği kullanılmıştır.

- Araştırmanın verilerinin analizinde tanımlayıcı analiz, ANOVA ve korelasyon analizi kullanılmıştır.

- Araştırma sonuçlarına göre; pazar kültürünün sürdürülebilir rekabet avantajını pozitif yönde etkilerken hiyerarşi kültürünün sürdürülebilir rekabet avantajını negatif yönde 
Canan Tiftik, “Türkiye'deki İşletmelerin Rekabet Kazanımlarında Kullandıkları Stratejik Yönetim Anlayışlarının Etkileri: Sistematik Bir İnceleme”, İzlek Akademik Dergi (Izlek Academical Journal), 4 (1), 2021, ss. 45-55.

etkilediği tespit edilmiştir. Aracılık etkisi test sonuçlarına bakıldığında ise; sürdürülebilir rekabet avantajının pazar, hiyerarşi kültürü ile kurumsal performans arasında kısmi aracılık etkisi olduğu saptanmıştır.

\section{TARTIȘMA}

Değişim ve dönüşümün oldukça sık yaşandığı, rekabet edebilme becerilerinin hayati önem taşıdığı günümüz dünyasında örgütler, varlıklarını sürdürebilmek için sahip oldukları kaynakları etkili ve verimli kullanmak zorundadır. Çünkü değişim ve belirsizliğe yol açan küreselleşme ve rekabet, örgütlerin yeni hedefler ve stratejiler geliştirmelerini zorunlu kılmaktadır (Ögüt, Akgemci ve Demirsek, 2004). Bu durum değișebilen, geliştirilebilen ve üretken bir kaynak olan insan kaynağının örgütler açısından önemini artırmaktadır (Bingöl, 2013). Çünkü örgütler sermaye, girişim, hammadde, enerji ve emek gibi üretim etmenleri yanında insan kaynağını kullanarak amaçlarını gerçekleştirmeye çalışır (Coşkun, Mesci ve Kılınç, 2013). Üretim sürecinde etkili olan diğer kaynaklarla karşılaştırıldığında, insan kaynağı kadar etkililiği ve verimliliği sağlayan bir kaynak olduğunu söylemek güçtür. İnsan kaynağı hem fiziksel hem de düşünsel gücü ile örgüte ve yönetime katılmakta, üretimde etkili olan kaynaklar üzerinde belirleyici bir role sahip olmaktadır. Ancak örgütler sahip oldukları insan kaynağı açısından farklılıklar göstermektedir. Çalışanlarının üretim süreçlerine katma değer vermelerini sağlayan, kolektif bilgi, beceri ve yetenek açısından eşsiz insan sermayesine sahip olan bir örgüt, diğer örgütlerle olan rekabette üstünlügü sağlamaktadır (Huselid, Jackson ve Schuler, 1997; İnce, 2006).

21. yüzyılda her tür ve düzeydeki örgüt, varlığını sürdürmek ve gelişebilmek için rekabet etmeyi, ürün kalitesini artırmayı veya verdiği hizmetlerde verimliliği sağlamayı hedeflemelidir. Özel kurumlarda/kuruluşlarda rekabet avantajı sahip olunan fiziksel ve mali sermayeden kaynaklanır. Oysa kamu kuruluşları için rekabet kavramının geçerliliği tartışmalı bir konudur. Ancak rekabetin olduğu kabul edilirse, kamu kuruluşları için rekabet avantajı politik desteklerle edinilen bir dizi kaynak (bina, araç-gereç, teknoloji vb.) ile örgütün sahip olduğu insan kaynağından oluşmaktadır (Mercin, 2005; Porter, 2007; Vandenabeele, 2013).

Tüm dünyada etkisini hissettiren Covid -19 sadece sağlığı tehdit eden bir salgın olmayıp, tüm dünya ekonomilerini ve sosyal yapıyı da etkileyerek alışa geldiğimiz yaşam tarzlarını, tüketim kalıplarını, alışkanlıklarımızı ve ilişkilerimizi kökten etkilemiştir. Pandemi nedeniyle uzun süredir devam tüketici alışkanlıkları değişmiş ve tatil, eğlence, ev dışı hizmetler gibi eskiden çoğunlukla yüz yüze verilen hizmetlere ayrılan bütçeler azalırken, ev malzemeleri ve evde spor ile ilgili harcamalar yükselmiştir. Ancak en bariz büyüme gösteren sektörlerin başında uzaktan verilmesine alışık olunan ve mesafe kurallarını ihmal etmeyen dijital hizmetlerin geldiği görülmüştür (Remes ve diğ., 2021). Buna göre, önceliği dijital olan ve çok kanallı pazarlama kullanan perakendeciler bu yeni ortama daha kolay uyum sağlamış, ancak çok kanallı stratejiler yerine fiziksel mağazalara ve yüz yüze etkileșime öncelik veren perakendeciler yanıt vermekte zorlanmışlardır (Briedis ve diğ., 2020).

Her tehdit bir fırsattır kuralı bu dönemde de işlemiştir. Altunışık'ın (2009) tarif ettiği değişen pazar şartları altında işletmenin geleceğinin şekillendirmesi için stratejik pazarlama yönetimi unsurları devreye girmiştir. Sonuç olarak bu salgının dünyayı, yaşam şeklini ve insanları değiştirdiği bir gerçektir. Olumsuzluklardan nasıl bir olumlu sonuç çıkarılacağı, kazanımların nasıl korunacağı işletmelerin strateji yönetimleri kapsamında yer almaktadır. Küreselleşme diye tabir ettiğimiz değişim rüzgârı Covid-19 ile yeni boyut kazanmıştır. 
Canan Tiftik, “Türkiye'deki İşletmelerin Rekabet Kazanımlarında Kullandıkları Stratejik Yönetim Anlayışlarının Etkileri: Sistematik Bir İnceleme”, İzlek Akademik Dergi (Izlek Academical Journal), 4 (1), 2021, ss. 45-55.

\section{SONUÇ}

Yeni normalde veri analitiğinin yalnızca tüketici tercihlerini ve davranışlarını ayrıntılı bir şekilde izlemesi değil, aynı zamanda fırsatlara veya tehditlere hızlı yanıt vermede de temel bir rol oynaması gerekmektedir. Özellikle mevcut analitik modeller, yeni normaldeki davranışları tahmin ederken yeterince başarılı olmayabilir. İşletme çalışanlarının yeni davranışsal verilerin en iyi şekilde nasıl kullanılacağı konusunda hızla eğitilme ihtiyaçları doğmuştur. Ekim 2021 itibariyle yapılan aşılama çalışmalarına rağmen COVID-19 pandemisi devam etmektedir. Bu anlamda, yeni normalde üzerinde durulması gereken önemli konulardan birinin işletmelerin belirleyeceği rekabet pozisyonu olduğu görülmektedir (Atmar ve diğ., 2020; Arora ve diğ., 2020). Yeni normalde işletmelerin rekabet sağlamalarında dijital mecralarda uygulanan stratejiler, dijital ortamlardan gelen yeni ve çok büyük miktarda verinin nasıl yönetileceği ve daha da daralan müşteri segmentlerine yönelik teklifleri ve mesajları daha iyi kişiselleştirmek için verilerin nasıl kullanılacağının düşünülmesi gerektiği savunulmaktadır.

Covid-19 insanları evde kalmaya zorladığında işletmelerin çok büyük bir kısmı bu duruma mümkün olduğunca adapte olmuştur. Bir yandan kamu kurumları, hizmetlerin aksamaması için teknoloji kullanımını artırırken, öte yandan işletmeler de var olma mücadelesi çerçevesinde tüketiciye çevrim içi ulaşabilecekleri her tekniğin üstüne gitmişlerdir. İşletmelerin buna yönelik yatırımlar yapmaları, salgın dönemi kazanılan alışkanlıklardan yola çıkarak daha inovatif fikir ve ürünlerle tüketicilerin karşısına çıkmaları, kendi ticari gelecekleri için olumlu bir süreç olacağı düşünülmektedir.

\section{Kaynakça}

ADABOR, H. (2019). Opening up strategy formulation: benefits, risks, and some suggestions. Business Horizons, 62, 383-393.

ALTUNIŞIK, R. (2009). Stratejik Pazarlama Planlaması. İstanbul: Beta Yayınları.

ARORA, A., DAHLSTRÖM, P., HAZAN, E., KHAN, H., \& KHANNA, R. (2020). Reimagining marketing in the next normal. McKinsey Article.

ATMAR, H., BEGLEY, S., FUERST, J., RICKERT, S., SLELATT, R., \& TJON PIAN GI, M. (2020). The next normal: Retail M\&A and partnerships after Covid-19. Mc Kinsey\& Company.

BİNGÖL, D. (2013). Insan kaynakları yönetimi (8. Baskı). İstanbul: Beta Yayıncılık.

BRIEDIS, H., KRONSCHNABL A., RODRIGUEZ A., \& UNGERMAN K. (2020). Adapting to the next Normal in Retail: The Customer Experience Imperative. McKinsey \& Company.

BURAK, M. F., \& DENIZ, R. B. (2021). Kurum Kültürü, Sürdürülebilir Rekabet Avantajı, Çevresel Belirsizlik ve Kurumsal Performans İlişkisi: Türk İhracatçı Firmaları. International Journal of Arts And Social Studies, 4(6), 49-83.

CALIK, M., \& SÖZBİLIR, M. (2014). Parameters of Content Analysis. Education and Science, 39(174), 33-38.

CEBECİ, H. İ. (2021). Artificial intelligence applications in management information systems: A comprehensive systematic review with business analytics perspective. Artificial Intelligence Theory and Applications, 1(1), 25-56. 
Canan Tiftik, “Türkiye'deki İşletmelerin Rekabet Kazanımlarında Kullandıkları Stratejik Yönetim Anlayışlarının Etkileri: Sistematik Bir İnceleme”, İzlek Akademik Dergi (Izlek Academical Journal), 4 (1), 2021, ss. 45-55.

COŞKUN, S., MESCİ, M., \& KILINÇ, İ. (2013). Stratejik Rekabet Üstünlüğü Sağlama Aracı Olarak İnovasyon Stratejileri: Kocaeli Otel İşletmeleri Üzerine bir Araştırma. AIBÜ̈ Sosyal Bilimler Enstitüsü Dergisi, 12(2), 101-132.

ÇAĞLI, A. (2019). Türkiye'de kuantum öğrenme üzerine yapılmış lisansüstü tezlerin incelenmesi (Yayımlanmamış yüksek lisans tezi). Burdur Mehmet Akif Üniversitesi, Burdur.

ÇATI, K., \& ÇIKMAK, S. (2021). Üretim İşletmelerinde Lojistik Faaliyetlerin Rekabet Algısı: Düzce İlinde bir Araştırma. https://www.researchgate.net/profile/Sinan-

Cikmak/publication/342742822 URETIM ISLETMELERINDE LOJISTIK FAALIYETLERIN REKA BET ALGISI DUZCE ILINDE BIR ARASTIRMA/links/5f046b4c92851c52d61de6d6/UeRETIMISLETMELERINDE-LOJISTIK-FAALIYETLERIN-REKABET-ALGISI-DUEZCE-ILINDE-BIRARASTIRMA.pdf, Erişim Tarihi: 10.10.2021

ÇELIKK, T. Z. (2020). Endüstri 4.0 İle Firmaların Rekabet Stratejileri Seçimleri ve Firma Büyüklügü Arasındaki İlişki: Gaziantep Makine Halısı Üreticileri Örneği. Gaziantep Üniversitesi Íktisadi ve İdari Bilimler Fakültesi Dergisi, 2(1), 1-14.

DURSUN, B. (2021). İnsan Kaynakları Yönetiminde Örgütsel Performans ve Jenerik Rekabet Stratejilerinin Etkisi Üzerine bir Araştırma: Kırklareli İli Örneği. Kırklareli Üniversitesi Sosyal Bilimler Meslek Yüksekokulu Dergisi, 1(1), 49-65.

ERDAĞ, T., \& YAŞLIOĞLU, M. (2020). Farklı Rekabet Stratejileri Benimseyen İki Havayolu İşletmesinin Kabin Görevlileri Tarafından Algılanan Örgütsel Desteğin Örgütsel Sessizliğe Etkisinin Karşılaştırması. İşletme Araştırmaları Dergisi, 12(4), 3383-3404.

HALLINGER, P. (2018). Surfacing A Hidden Literature: A Systematic Review Of Research On Educational Leadership and Management in Africa. Educational Management Administration \& Leadership, 46(3), 362-384.

HUSELID, M. A., JACKSON, S. K., \& SCHULER, R. S. (1997). Technical and Strategic Human Resources Management Effectiveness as determinants of Firm Performance. Academy of Management Journal, 40(1), 171-188.

İNCE, M. (2006). Değişim Olgusu ve Örgütlerde İnsan Kaynakları Yönetiminin Değișen Fonksiyonları. Selçuk Üniversitesi Sosyal Bilimler Enstitüsü Dergisi, 14, 319-339.

KAYA, M. C., BATMAN, O., \& TÜRKAY, O. (2021). Otel İșletmelerinde Rekabet Üstünlüğü Sağlayan Kritik Başarı Faktörleri: Trabzon İlindeki 4 ve 5 Yıldızlı Oteller Üzerine bir Araştırma. Türk Turizm Araştırmaları Dergisi, 5(1), 346-364.

MERCIN, L (2005). İnsan Kaynakları Yönetiminin Eğitim Kurumlan Açısından Gerekliliği ve Geliștirme Etkinliği. Elektronik Sosyal Bilimler Dergisi, 4(14), 128-144.

ORAKCIOĞLU, E. (2019). Türkiye'de uzaktan eğitim temalı 2013-2018 yılları arasında yapılan lisansüstü tezlerin incelenmesi (Yayımlanmamıș yüksek lisans tezi). Eskișehir Osmangazi Üniversitesi, Eskisehir.

ÖĞÜT A., AKGEMCİ, T, \& DEMİRSEK, M. T. (2004). Stratejik İnsan Kaynakları Yönetimi Bağlamında Örgütlerde İşgören Motivasyonu Süreci. Selçuk Üniversitesi Sosyal Bilimler Enstitüsü Dergisi, 12, 277-290. 
Canan Tiftik, "Türkiye'deki İşletmelerin Rekabet Kazanımlarında Kullandıkları Stratejik Yönetim Anlayışlarının Etkileri: Sistematik Bir İnceleme”, İzlek Akademik Dergi (Izlek Academical Journal), 4 (1), 2021, ss. $45-55$.

ÖZDEMIR, B., \& TAŞCI, D. (2020). Kaynak Temelli Görüş Ekseninde Örgütsel Kaynakların Rekabet Stratejileri Üzerindeki Etkisi: Türkiye'nin İlk 1000 Büyük Sanayi Kuruluşu'nda bir Araştırma. Eskişehir Osmangazi Üniversitesi İktisadi ve İdari Bilimler Dergisi, 15(3), 1019-1042.

ÖZER, K. O., SALDAMLI, A., \& CINNIOĞLU, H. (2021). Stratejik Yetenek Yönetimi ve Sürdürülebilir Rekabet Avantajı İlişkisinde Örgütsel Bağlılığın Rolü. Abant Sosyal Bilimler Dergisi, 21(1), 223238.

PORTER M. E., (2007). Rekabet Stratejisi: Sektör ve Rakip Analizi Teknikleri (Çev: Gülen Ulubilgen). İstanbul: Sistem Yayıncllı.

REMES J., MANYIKA J., SMIT S., KOHLI S., FABIUS V., DIXON-FYLE S., \& NAKALIUZHNYI A. (2021). The Postpandemic Economy: The Consumer Demand Recovery and Lasting Effects of Covid-19. Mckinsey \& Company.

VANDENABECLE, W. (2013). Motivation, Job Satisfaction and Retention/Turnover in the Public Sector. In, R. J. Burke, A. J. Noblet, and C L. Cooper (Ed.), Human resource management in the public sector (pp. 214-235). Cheltenham: Edward Elgar Publishing Limited.

YILDIRIM, S. K. (2020). Otel İşletmelerinde Dönüştürücü Liderliğin Rekabet Zekâsına Etkisinde Örgütsel Öğrenmenin Aracılık Rolü. Türk Turizm Araştırmaları Dergisi, 4(3), 2244-2263.

YILDIRIM, Y., \& ÇAKIRLI, H. (2021). Konaklama İşletmelerinde Rekabet Avantajı Kaynakları: Bodrum Örneği. IBAD Sosyal Bilimler Dergisi, (7), 207-221.

YILDIZ, D., \& GENÇ, K. Y. (2020).Sürdürülebilir rekabet üstünlüğünde entelektüel sermayenin önemi: kaynak tabanlı bir yaklaşım. Asya Studies, 4(14), 119-134. 